\title{
AN INSTRUMENT TO MEASURE FOREST CROWN COVER
}

\author{
BY MARK W. ROBINSON
}

\author{
Dominion Forest Service, Ottawa, Ontario
}

$\mathrm{T}$

HE BASIC factor in the preparation of any forest estimate from information collected on the ground is the volume of the individual tree calculated from its height and diameter at breast height. This method is not applicable to estimates from the majority of summer air photographs, or from those of dense stands of conifers in winter photographs because numbers of trees and details of individual trees cannot be ascertained in any except open stands shown on summer photographs, or in dense softwood stands seen on a winter photograph.

Though measurements of thousands of plots are available, these are of no value for estimating from air photographs because of the lack of correlation between the information used to calculate their volume and the data which can be secured from air photographs. In other words, a new factor must be introduced, and additional information in relation thereto taken on the old plots, or derived from new plots. It is considered that the degree of crown cover is the most valuable measurable factor, besides height, which can be used in the preparation of forest estimates from summer photographs of stands having a high degree of crown cover, or from winter photographs of. dense softwood stands.

Measurement of tree heights on air photographs has been very ably covered in other articles and will not be discussed here.

The first attempt at estimation of crown cover was ocular. This, as was expected, proved too unreliable for accurate work.

The photo-electric cell was tried as a means of measuring the percentage of crown cover. This was found unsatisfactory for the following reasons:-

(1) It did not differentiate between a thin crown and small gaps in a dense crown;

(2) It could not be used for measuring the percentage of crown cover of hardwoods in the wintertime.

In order to get over these diffculties, an instrument was evolved which, because of the peculiar appearance of the pilot model, was immediately dubbed the "Moosehorn". This consists of:-

(a) An inverted pyramid (see Plate 1), approximately 12.5" in height and $8.5 "$ square at the large end with a handle at the point, and an aperture just above the handle.

(b) A mirror set in front of the aperture at $45^{\circ}$ to the axis of the pyramid. This permits a view of the complete open end of the pyramid.

(c) A plexiglass top divided into nine equal squares, each of which contains 25 equally spaced dots. Nine squares were originally adopted to offset errors arising from possible tilt of instrument by providing a generous overlap It was found in practice that the results from the centre square are seldom very far from the mean of the nine. 
Probably the most serious complaint about the instrument is the awkward size, which is a definite drawback in thick woods. Plans are being drawn for a smaller though more expensive model incorporating lenses. Should the utility of the instrument justify construction in greater numbers, this smaller model will be constructed.

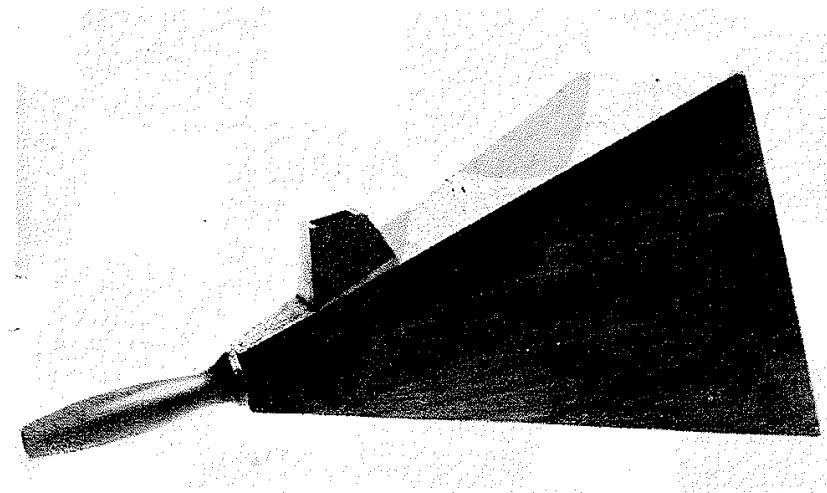

Plate 1

$$
\text { Instructions for Use: }
$$

(1) A two-man team is required -

(i) "Moosehorn" operator to take the readings;

(ii) A tally-man to record.

(2) Readings are to be taken at regular intervals, spaced so that each reading overlaps the preceding ones. Normally 20 readings are taken on a quarter-acre plot; if time permits 40 are preferable. Either 20 or 40 readings should be taken.

(a) To avoid possible error from slight tilt of the "Moosehorn" by the operator;

(b) To simplify the calculation of percentages.

(3) The "Moosehorn" is to be held in a vertical position (See Plate 2) so that the operator can view the crown cover through the side aperture. Square by square the operator counts the dots which fall in the open spaces, calling them off "square 1-9 dots," "square 2-11 dots", etc. The tally'man records these on the tally and computation sheet (see Plate 3). Dots falling in the open spaces are used in preference to those falling in tree crown because of greater contrast.

The crown cover of shrubbery or suppressed trees must not be included in the tally as this foliage is not visible on the air photographs and could not figure in an estimate of density made from them. Such growth can be easily eliminated in winter, but great care must be exercised in summer if the readings are to be evenly spaced and suppressed trees avoided. 
In taking winter readings of hardwood stands, estimates must be made of the probable summer coverage of the foliage, particular care being taken to eliminate dead branches when making the estimate.

Computation is made as shown in Plate 3. The dots of each square are added for the 20 or 40 readings and the results multiplied by .2 or .1 respectively. These figures are subtracted from 100, giving the percentage of crown cover indicated by each square of the "Moosehorn". An average of these figures gives the percentage of crown cover for the plot.

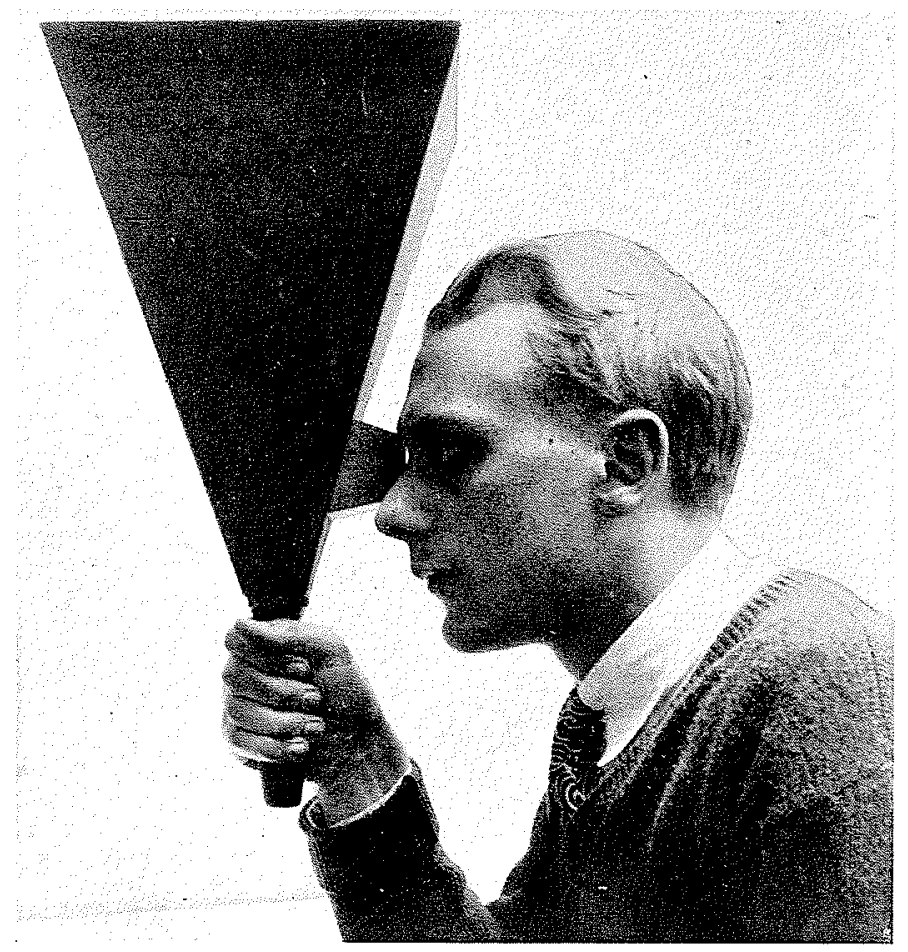

Plate 2

Since the average height varies with every stand the "Moosehorn" was constructed for determination of the percentage of crown cover only, rather than to cover a specific number of square feet at any one reading.

In order to tie the actual cubic volume, on measured plots, to the percentage of crown cover, the Air Surveys Division of the Dominion Forest Service, Department of Mines and Resources, takes "Moosehorn" readings as part of the regular plot procedure. In this way actual ground measurements are correlated with the measurable factors of the air photograph, and one step nearer the realization of stand volume tables is taken. 
Plate 3

MOOSEHORN

\begin{tabular}{|c|c|c|c|c|c|c|c|c|c|}
\hline \multirow{2}{*}{\multicolumn{10}{|c|}{ Type: Jack Pine }} \\
\hline & & & & & & & & \multirow{2}{*}{\multicolumn{2}{|c|}{$\begin{array}{l}\text { J.S.M. } \\
\text { O.N.R. }\end{array}$}} \\
\hline \multicolumn{4}{|c|}{ Date: 11 Oct. 1946} & \multicolumn{2}{|c|}{ Plot 4} & \multicolumn{2}{|c|}{$\begin{array}{l}\text { Tally } \\
\text { Instru. }\end{array}$} & & \\
\hline Read'g & 1 & 2 & 3 & 4 & 5 & 6 & 7 & 8 & $\overline{9}$ \\
\hline 1 & 3 & 12 & 11 & 2 & 11 & 22 & 3 & 1 & $\overrightarrow{22}$ \\
\hline 2 & 0 & 7 & 11 & 2 & 10 & 2 & 4 & $\overline{9}$ & 6 \\
\hline 3 & 1 & 5 & 11 & 6 & 11 & 9 & 7 & 3 & 1 \\
\hline 4 & 4 & 22 & 3 & 21 & 14 & 2 & 24 & 6 & 6 \\
\hline 5 & 1 & 3 & 8 & 0 & 2 & 14 & 15 & 21 & 5 \\
\hline 6 & $1 \overline{4}$ & 8 & 1 & 15 & 8 & 5 & 5 & 0 & 11 \\
\hline 7 & 0 & 20 & 16 & 11 & 9 & 2 & 16 & 5 & 9 \\
\hline 8 & 1 & 0 & 1 & 0 & 2 & 6 & 6 & 15 & 8 \\
\hline 9 & 0 & 1 & 11 & 1 & 1 & 7 & 6 & 5 & 12 \\
\hline 10 & 17 & 18 & 8 & 21 & 25 & 25 & 19 & 20 & 6 \\
\hline 11 & 2 & 2 & 14 & 10 & 7 & 18 & 17 & 21 & 22 \\
\hline 12 & 0 & $1 \overline{4}$ & 20 & 0 & 14 & 16 & 0 & 10 & 15 \\
\hline 13 & 17 & 3 & 4 & 11 & 2 & 0 & 3 & 5 & 0 \\
\hline 14 & 2 & 0 & 10 & 0 & 0 & 19 & 2 & 0 & 3 \\
\hline 15 & 1 & 20 & 13 & 16 & 1 & 2 & 22 & 0 & 13 \\
\hline 16 & 11 & 22 & 6 & 14 & 4 & 14 & 6 & 3 & 13 \\
\hline 17 & 18 & 25 & 9 & 6 & 25 & 25 & 1 & 9 & 9 \\
\hline 18 & 0 & 7 & 17 & 9 & 15 & 10 & 5 & 4 & 1 \\
\hline 19 & 21 & 21 & 8 & 25 & 24 & 7 & 25 & 14 & 0 \\
\hline \multirow[t]{3}{*}{20} & 3 & 15 & 25 & 0 & 15 & 25 & 1 & 5 & 19 \\
\hline & 116 & 225 & 207 & 170 & 200 & 230 & 187 & 156 & 181 \\
\hline & .2 & .2 & .2 & .2 & .2 & .2 & .2 & .2 & .2 \\
\hline \multicolumn{2}{|c|}{$\begin{array}{c}\% \text { of Gaps } \\
23.2\end{array}$} & 45.0 & 41.4 & 340 & 400 & 460 & 374 & 312 & 36.2 \\
\hline \multirow{2}{*}{\multicolumn{2}{|c|}{$\begin{array}{r}100.0 \\
23.2\end{array}$}} & 100.0 & 100.0 & 100.0 & 100.0 & 100.0 & 100.0 & 100.0 & 100.0 \\
\hline & & 46.0 & 41.4 & 34.0 & 40.0 & 46.0 & 37.4 & 31.2 & 36.2 \\
\hline \multicolumn{2}{|c|}{$\begin{array}{c}\% \text { of Crown } \\
76.8\end{array}$} & $\begin{array}{c}\text { Cover } \\
55.0\end{array}$ & 58.6 & 66.0 & 60.0 & 54.0 & 62.6 & 68.8 & 63.8 \\
\hline
\end{tabular}

The few plots already measured show a relation between percentages of crown cover and volume for any one height class. Should further plots prove this relationship consistent, the measurement of any plot could be easily converted into figures suitable for the preparation of height-stand crown cover tables.

Since the use of air photographs for forestry purposes will most certainly increase in the future, the need for an accurate method of estimating crown cover and preparing stand volume data which will utilize factors measurable on the photographs becomes increasingly important. The greatest obstacle to the solution of this problem at the present time is lack of accurate data. Use of the instrument by interested organizations will, it is anticipated, provide the additional data needed. 